\title{
Karl Marx: an early post-Keynesian? A comparison of Marx's economics with the contributions by Sraffa, Keynes, Kalecki and Minsky*
}

\author{
Eckhard Hein** \\ Berlin School of Economics and Law, Institute for International Political Economy (IPE), Germany
}

\begin{abstract}
This paper compares Marx's economics with those by Sraffa, Keynes, Kalecki and Minsky. The paper takes an 'ex post' view on the matter and looks at the output side of the respective authors, but not at the input side. This means no attempt is made to study in a systematic way whether and to what extent Sraffa, Keynes, Kalecki and Minsky were individually influenced by Marx's work. First, the relationship between Marx's theory of value and Sraffa's reformulation of the classical theory of prices and distribution is reviewed. Then the relationship between Marx's and Keynes's monetary theory is examined, relying on an interpretation of Marx's theory of value as a 'monetary theory of value'. Next, some light is shed on the Marx-Kalecki connection, focusing on Marx's theory of simple and extended reproduction and the built-in, although not fully elaborated, "principle of effective demand' and the related theories of distribution and accumulation. Finally, Marx's and Minsky's views on financial instability and crises are scrutinised. It is concluded that Marx should not be considered as an 'early post-Keynesian' but rather as an important forerunner of modern post-Keynesianism, with certain similarities, but also some important differences, and several areas of compatibility.
\end{abstract}

Keywords: Marx, Kalecki, Keynes, Minsky, Sraffa, comparison of economic theories

JEL codes: $B 14, B 24, B 50, B 51, E 11, E 12$

\section{INTRODUCTION}

Karl Marx's 200th birthday, on 5 May 2018, triggered conferences all over the world and several academic papers reflecting again on different aspects of his work, its impact and its

* Based on presentations at the 10th Anniversary Conference of the Institute for International Political Economy Berlin (IPE), 'Studying Modern Capitalism - The Relevance of Marx Today', Berlin, 12-13 July 2018, and the 22nd conference of the Forum for Macroeconomics and Macroeconomic Policies (FMM), 'Ten Years After the Crash - What Have We Learnt?', Berlin, 25-27 October 2018. I am most grateful to Fritz Helmedag, Hansjörg Herr and Heinz D. Kurz for helpful comments and suggestions and to Luke Neal and Sophie-Dorothee Rotermund for editing assistance. Remaining errors are mine, of course. In this paper, I am drawing freely on my earlier work on the issue (Hein 1997; 2004a; 2006; 2018a; 2018b).

** Email: eckhard.hein@hwr-berlin.de.

Received 25 March 2019, accepted 28 April 2019 
current relevance, not only in economics. ${ }^{1}$ The current contribution will focus on the relationship between Marx's economics and post-Keynesian economics, applying a 'broad tent approach' to the latter (Hein 2017). Following Lavoie (2014: ch. 1), post-Keynesian economics is assumed to include the following strands or sub-schools: First, the fundamentalist Keynesians, directly inspired by John Maynard Keynes and the older Joan Robinson, as well as Hyman Minsky, G.L.S. Shackle and Sydney Weintraub, with their major themes of fundamental uncertainty, the features of a monetary production economy, financial instability and methodological issues; second, the Kaleckians, drawing on the works of Michał Kalecki, Josef Steindl and the younger Joan Robinson, with the themes of cost-plus pricing, class conflict, effective demand, income distribution and growth; third, the Kaldorians, basing their work on the contributions by Nicholas Kaldor, Roy F. Harrod, Richard Goodwin, John Cornwall and Wynne Godley, the major themes being economic growth, productivity regimes, open-economy constraints to growth, and the nexus between the economic and the financial system; fourth, the Sraffians or neo-Ricardians, drawing on the work of Piero Sraffa and Pierangelo Garegnani, and focusing on issues like relative prices in multi-sectoral production systems, choice of techniques, capital theory and long-run positions of the economy; and fifth, the Institutionalists, relying on the work of Thorstein Veblen, Gardiner Means, P.W.S. Andrews, John Kenneth Galbraith, Abba Lerner and Alfred Eichner, whose concentration has been on themes like pricing, the theory of the firm, monetary institutions, and behavioural and labour economics.

Of course, starting with the publication of Keynes's (1936) General Theory, comparing Keynes's and Marx's work on money, effective demand and economic development has attracted several researchers, partly also including Kalecki's or Minsky's work in their considerations. The papers or books by Fan-Hung (1939), Alexander (1940), Robinson (1966), Kenway (1980), Dillard (1984), Crotty (1986; 1993), Foley (1986a), Sardoni (1987; 2011), Rotheim (1991), Hein (1997; 2004a; 2006) and Argitis (2001) are just a few examples.

It is well known that Keynes's views on Marx's economics were not very favourable, although he even made use of Marx's famous $M-C-M^{\prime}$ circuit of capital (Keynes 1933a [1979]: 81), that is, capitalists advancing money $(M)$ in order to purchase commodities $(C)$, both means of production and labour power, the product of which is then exchanged against more money $\left(M^{\prime}\right)$. But, for example, Keynes (1936 [1973]: 355) believed 'that the future will learn more from the spirit of Gesell than from that of Marx', and he turned Marx's (1867) Capital down, arguing that 'whatever the sociological value of the latter, I am sure that its contemporary economic value ... is nil' (Keynes 1934 [2013]: 38).

However, eminent post-Keynesians, such as Robinson (1942; 1966), Steindl (1952 [1976]: ch. XIV) and Kalecki (1968), have assessed at least certain aspects of Marx's economics quite positively and have even built part of their own work on Marx. But looking at the current debates in post-Keynesian economics, dealing with Marx seems to be somewhat out of fashion. In Lavoie's (2014) benchmark advanced textbook, Post-Keynesian Economics: New Foundations, there is no reference to Marx at all in the bibliography - though at least Marx appears in the name index. ${ }^{2}$ In his earlier Introduction to Post-Keynesian Economics,

1. For contemporary papers see, for example, Bellofiore (2018), Boyer (2018), Fine/Saad-Filho (2018), Gehrke/Kurz (2018), Howard/King (2018), Kurz (2018a; 2018b), McDonough/McMahon (2018), Toporowski (2018) and (further) contributions to the special issues on Marx's 200th birthday of the The European Journal of the History of Economic Thought, 2018, 25(5) and the Review of Political Economy, 2018, 30(3).

2. I have to admit that in my recent Distribution and Growth After Keynes: A Post-Keynesian Guide (Hein 2014), which grew out of an earlier German book on the same topic (Hein 2004b), I abandoned the consideration of Marx's work, and also Smith's and Ricardo's, in order to have more space 
however, Lavoie (2006: 3) has Marx as an antecedent of post-Keynesian economics in his overview table, with an influence on post-Keynesian economics via Kalecki. This is also how I have been teaching heterodox and orthodox schools in macroeconomics, making use of a variation of Lavoie's figure, as can be seen in Figure 1.

In this paper, however, I will take a broader perspective and review the similarities and the differences of Marx's economics not only with Kalecki's contributions, but also with those by Sraffa, Keynes and Minsky, so that we have major representatives of three out of the five strands of post-Keynesian economics mentioned above. Kaldor, Robinson and Steindl would have been further candidates to be discussed, but space constraints do not allow for a review of the similarities of their work with Marx's in the current paper. The paper will take an 'ex post' view on the matter and look at the 'output side' of the respective authors, but not as much at the 'input side'. This means no attempt will be made at studying in any systematic way whether and to what extent Sraffa, Keynes, Kalecki and Minsky were individually influenced by Marx's work. In Section 2, the relationship between Marx's theory of value and Sraffa's reformulation of the classical theory of prices and distribution will be reviewed. Section 3 will then turn towards the relationship between Marx's and Keynes's monetary theory, relying on an interpretation of Marx's theory of value as a 'monetary theory of value'. Section 4 will build on Marx's monetary theory and review the Marx-Kalecki connection, focusing on Marx's theory of simple and expanded reproduction and the built-in, although not fully elaborated, 'principle of effective demand' and the related theories of distribution and accumulation. Section 5 will then consider Marx's and Minky's views on financial instability and crises. Section 6 will briefly summarise and conclude that, of course, Marx should not be considered as an 'early post-Keynesian' but rather as an

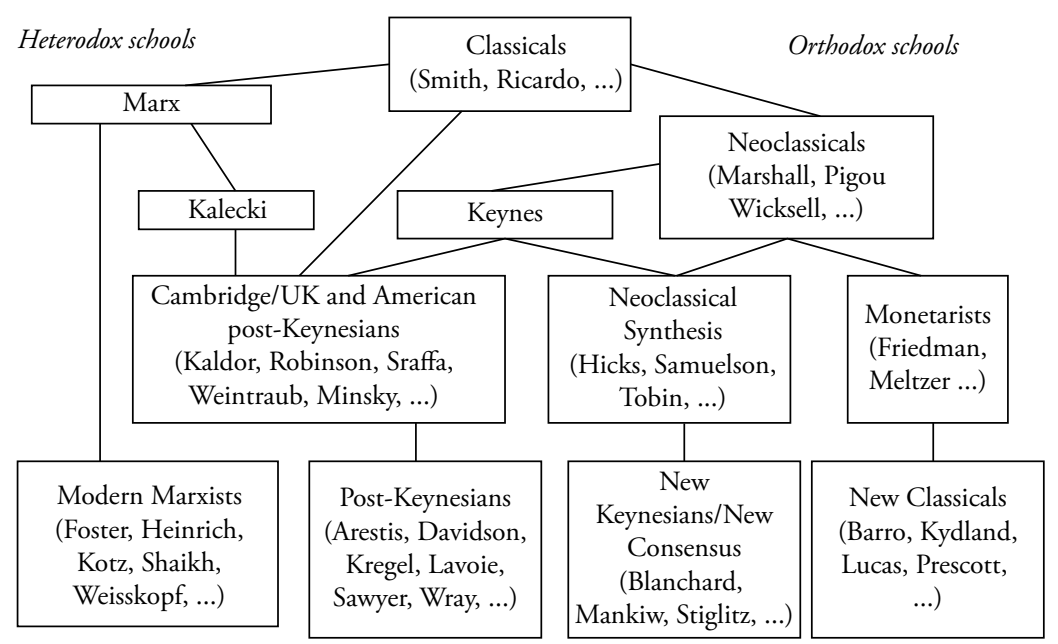

Figure 1 Heterodox and orthodox schools in macroeconomics

\section{(footnote 2 continued)}

for an in-depth presentation and discussion of post-Keynesian distribution and growth theories, and of recent Kaleckian models in particular. But in the second edition of my German book on distribution and growth theories (Hein 2018c), I kept the chapters on the classicals and on Marx, even extending them. But I did not provide any systematic comparison of Marx's and post-Keynesian economics on a broader scale. 
important forerunner of modern post-Keynesianism, with different similarities and several areas of compatibility.

\section{MARX AND SRAFFA: LABOUR THEORY OF VALUE AND PRICES OF PRODUCTION}

Following the classical tradition, Marx's theory of value and distribution generally agrees with the classical view, rigorously reformulated by Sraffa (1960), that long-run equilibrium prices are determined by costs and the requirements of reproduction of the system as a whole. However, Marx is convinced that at the very foundation of this price determination there is a labour theory of value, according to which 'socially necessary labour time' determines value and thus, under certain conditions, relative prices in long-run equilibrium.

In Capital, Volume 1, Marx's analysis of capitalist reproduction starts with the consideration of the commodity as the product of individual labour in capitalist market economies, characterised by the social division of labour (Marx 1867 [1967]: part I). The coordination of the social division of labour takes place in the market sphere, where private individual labour expended has to prove that it is a necessary part of the social expenditure of labour, that is, private labour has to prove to be 'socially necessary'. 'Socially necessary labour time' thus determines the exchange value of commodities, according to Marx. ${ }^{3}$

However, as then becomes clear in Capital, Volume 3, compiled and edited by Friedrich Engels, with different technical conditions of production in different industries but the same rate of exploitation of labour, relative prices determined by labour values will lead to different rates of profit and thus violate the notion of a general rate of profit in long-run equilibrium (Marx 1894 [1967]: part II). The rate of exploitation or the rate of surplus value $\left(m^{\prime}=s / v\right)$ relates surplus value $(s)$ to variable capital, which is the value of labour power or wages advanced $(v)$. The value of labour power is determined by the value of the bundle of produced commodities required for the reproduction of workers and their families, and surplus value is given by the value of the remaining bundle of produced commodities acquired by capitalists. The rate of profit $[r=s /(c+v)]$ relates surplus value to total capital advanced, consisting of variable capital and constant capital $(c)$, which is the value of raw materials, intermediate products, machines, buildings, etc. It is obvious that with the same rate of exploitation across different industries, established through the movement of labour between different occupations and industries, the rates of profit across industries $\left(r_{i}\right)$ will vary according to the different organic composition of capital $(c / v)_{i}$ of these industries:

$$
r_{i}=\frac{s_{i}}{c_{i}+v_{i}}=\frac{\frac{s}{v}}{\left(\frac{c}{v}\right)_{i}+1} .
$$

3. Identifying socially necessary labour time as the 'common third' underlying the exchange of commodities is therefore a result of Marx's basic question, asking how social coherence in a decentralised system of production and expenditure of labour is established. Technically, Kurz (2018a) is of course right, arguing that any (composite) commodity can be the 'common third' in which the relative value of each commodity is expressed. Following Marx's starting point and line of reasoning in Capital, Volume 1, part I, will thus not lead to an adequate and logically consistent theory of long-run prices. However, through the development of the value form, and finally the money form, Marx provides the conditions for monetary analysis in this part, as will be explained in the following section on Marx and Keynes. 
Therefore, with the establishment of a general rate of profit as a long-run equilibrium condition, because only then will there be no inducement to shift capital between industries any more, the related prices of production will have to deviate from prices determined by labour values. However, Marx still claimed that in the aggregate the labour theory of value will hold, that is, the sum of prices of production will be equal to the sum of prices proportional to labour values, the sum of profits in the price system will be equal to the sum of the monetary expression of surplus values, and the rate of profit in the value system will be equal to the rate of profit in the price system (Marx 1894 [1967]: ch. X). But the following discussion on the 'transformation problem', starting with von Bortkiewicz (1907), has shown that Marx's method of transforming labour values into prices of production is at best incomplete and that the results are thus generally flawed. ${ }^{4}$ This becomes immediately clear if we conceive of profits as a valued bundle of produced commodities acquired by capitalists, and of the rate of profit as the ratio of this valued bundle to the valued means of production plus the value of labour power, represented by the valued bundle of commodities acquired by workers. Since Marx concedes that, under the conditions explained above, the price of production of a single commodity may deviate from its labour value, this can then also be true for the respective bundles of commodities and thus also for the ratio of these bundles representing the rate of profit. None of Marx's propositions for the aggregate economy is therefore generally true. ${ }^{5}$

Neo-Ricardian critics, in particular Steedman (1977: ch. 3), have thus argued that labour values are redundant and hence not required for the calculation of long-run equilibrium prices of production (see also Kurz 2018b). Following Sraffa (1960), the calculation of long-run equilibrium prices requires information about the production technology, represented by the production coefficients $\left(a_{i j}\right)$ and the labour coefficient $\left(a_{0 j}\right)$, as well as a distribution parameter, either the real wage rate $(w)$, that is, the bundle of commodities acquired by workers, or the rate of profit $(r)$. This is shown in equation (2) for a system of $n$ industries producing a single commodity each with only circulating constant capital, but without fixed constant capital, in which wages are advanced ex ante by capitalists:

$$
\begin{aligned}
& \left(a_{11} p_{1}+a_{21} p_{2}+\ldots+a_{n 1} p_{n}+a_{01} w\right)(1+r)=p_{1} \\
& \left(a_{12} p_{1}+a_{22} p_{2}+\ldots+a_{n 2} p_{n}+a_{02} w\right)(1+r)=p_{2} \\
& \ldots \\
& \left(a_{1 n} p_{1}+a_{2 n} p_{2}+\ldots+a_{n n} p_{n}+a_{0 n} w\right)(1+r)=p_{n} .
\end{aligned}
$$

With knowledge of the production technology and one distribution parameter, the $n-1$ relative prices, taking one of the $n$ commodities as a numeraire, and the remaining distribution parameter are uniquely determined - and labour values are thus redundant for the calculation of relative prices of production. ${ }^{6}$

However, even if Marx's labour theory of value cannot be sustained as a theory of relative prices, Marx, together with the other classical authors, has contributed to an understanding of the system of production as a circular flow of commodities, as Kurz (2018b)

4. For summaries, see, for example, Foley (2000), Glick/Ehrbar (1987) and Hunt/Glick (1987).

5. For an attempt at rescuing the labour theory of value by equating the rate of profit with the rate of surplus value, see Helmedag $(2012 ; 2018)$. This attempt, however, disregards fixed constant capital and interprets circulating constant capital as the result of labour expended in the current period. Obviously, this is hardly in line with Marx's initial thoughts.

6. The calculation of labour values also requires the same information about the production technology, as shown by Steedman (1977: ch. 3). 
has recently reminded us. This understanding has provided the grounds for the determination of equilibrium prices by costs and the requirements of reproduction of the system as a whole, as demonstrated by Sraffa (1960). Since a distribution parameter needs to be known in order to derive relative prices, such a system provides the grounds for a fundamental critique of aggregate neoclassical theory, deriving the real rate of interest from the marginal product of aggregate capital (as a valued bundle of commodities), as has been shown in the Cambridge-Cambridge capital controversies. ${ }^{7}$ On the other hand, such an approach requires a theory of functional income distribution different from marginal productivity theory, and it has thus provided the foundations and the justification for different post-Keynesian theories of distribution. ${ }^{8}$ These include Sraffa's (1960) original closure of the price system by a subsistence or conventional real wage rate, in line with the arguments in Ricardo and Marx; the determination of the equilibrium rate of profit by an exogenous monetary rate of interest, as also suggested by Sraffa (1960:33) and then picked up by modern neo-Ricardians (Panico 1985; Pivetti 1985; 1991); the determination of the equilibrium rate of profit by capitalist expenditures, as in Kaldor's (1955/1956) and Robinson's (1962: ch. II) original contributions, based on Keynes's (1930 [1971]: ch. 10) Treatise on Money; and also the determination of the profit share by mark-up pricing and relative powers of capitalists and workers in the goods and in the labour market, ${ }^{9}$ as in Kalecki (1954: ch. 2) and Steindl (1952 [1976]: part I) and in the modern neo- and postKaleckian distribution and growth models (Rowthorn 1981; Dutt 1984; Bhaduri/Marglin 1990; Kurz 1990).

\section{MARX AND KEYNES: MONETARY THEORY OF VALUE AND MONETARY THEORY OF PRODUCTION}

Although Marx's labour theory of value is not sustainable as the basis of a theory of relative long-run prices, it provides the foundation for Marx's version of 'monetary analysis'. 'Monetary Analysis introduces the element of money on the very ground floor of our analytical structure and abandons the idea that all essential features of economic life can be represented by a barter-economy model', according to Schumpeter (1954: 278). Marx's monetary analysis thus allows us to draw conclusions which meet Keynes's requirements of a 'monetary theory of production', as spelt out in his contribution to the Spiethoff Festschrift:

In my opinion the main reason why the problem of crises is unsolved $\ldots$ is to be found in the lack of what might be termed a monetary theory of production. ... The theory which I desiderate would deal ... with an economy in which money plays a part of its own and affects motives and decisions and is, in short, one of the operative factors in the situation, so that the course of events cannot be predicted either in the long period or in the short, without a knowledge about the behaviour of money between the first state and the last. (Keynes 1933b [1973]: 408-409, emphasis in original)

7. For an overview of the Cambridge-Cambridge controversies on the theory of capital, see Harcourt (1969; 1972), Lazzarini (2011) and Moss (1980), for example.

8. For a critique of the neoclassical theory of distribution based on an aggregate production function and an overview of alternative post-Keynesian theories of distribution, see Hein (2014: chs 3-5).

9. Due to the medium- to long-run endogeneity of the rate of capacity utilisation, however, the determination of the profit share in Kaleckian or Steindlian distribution and growth models does not uniquely determine the equilibrium profit rate, as in the other post-Keynesian models. 
In Capital, Volume 1, part I, Marx (1867) develops an analysis of the value form proving the requirement of a general equivalent, that is money, for market exchange as the dominant way of coordinating the social division of labour in a capitalist economy. This has given rise to the interpretation of Marx's theory of value as a 'monetary theory of value', already in the early work by Rubin (1928) and then in the more recent contributions by Reuten (1988; 1995), Heinrich (1991), Matthews (1996) and Williams (2000), among others. There it is argued that the category of value in Marx's theory necessarily includes the category of money and that the theory of value has to contain a theory of money, too. From this it follows that Marx's theory of value cannot be seen as a 'labour embodied theory of value' and his theory of money need not be interpreted as a 'commodity theory of money'. Rather, Marx's theory of value can be interpreted as a 'monetary theory of value' and his theory of money as a 'token' or even a 'credit theory of money'.

As explained in the previous section, in Capital, Volume 1, part I, Marx (1867) claims that in a capitalist economy the value of individual commodities is determined by 'socially necessary labour time', which is defined as follows: First, it is labour performed under the average technical conditions of production and with average skills and intensity (Marx 1867 [1967]: 47). Second, it requires that the product can be sold in the market sphere (Marx 1867 [1967]: 109). For the substance of value in Marx's economics, we thus obtain 'abstract labour' which is only constituted by exchange and which as such does not exist prior to the circulation of commodities. Value can therefore only be expressed and measured in a social category and thus requires the existence of a 'universal equivalent' as representative of abstract labour and social value to which the product of individual labour can be related.

Developing the 'money form' through a succession of the 'elementary or accidental form of value', the 'total or expanded form of value' and the 'general form of value', Marx (1867 [1967]: 54-75) demonstrates the necessity of such a universal equivalent for capitalist reproduction. Money as the result of the development of the value form should therefore not be seen as a device facilitating the exchange of commodities starting from a barter economy, but as an indispensable condition for commodity production and exchange in a capitalist economy (Williams 2000). Marx's claim that only a commodity (gold) which incorporates value itself can be money (Marx 1867 [1967]: 75) is not consistent with the 'monetary theory of value' sketched above, as Heinrich (1991), Matthews (1996), Reuten (1988; 1995) and Williams (2000) have pointed out. Since money has to represent 'abstract labour', its value cannot be determined by the amount of 'concrete labour' expended in the production of a certain money commodity. Money, rather, is a socially accepted representative of the universal equivalent which has to be guaranteed by social institutions. Gold may therefore be money, not because it is a commodity but because it is a socially accepted representative or token of value. Gold as a money commodity is, therefore, historically contingent but not theoretically necessary.

An understanding of money as a socially accepted token of value is perfectly compatible with the modern credit money system which can be described as a hierarchy of promises to pay, with increasing social validity and liquidity from the bottom to the top, as also conceived in modern post-Keynesian monetary theory (Evans 1997; Foley 1987; Smithin 1994: 72-90). The ultimate means of payment on the national level is the 'promise to pay' issued by the social institution 'central bank', i.e. central-bank money. On the international level, it is central-bank money issued by the central bank of the dominant country that is providing the world economy with key currency.

If a money commodity is rejected, the level of prices cannot be determined as in Marx's commodity theory of money, where the price level is given by the ratio of the weighted average labour value of the commodities in circulation to the labour value of a unit of the 
money commodity (Marx 1867 [1967]: ch. III). As Foley (1983) has suggested, the level of prices and the value of money are, rather, given by entrepreneurial pricing which itself may depend on the trend of accumulation and on the distribution struggle between capital and labour. The money wage rate will therefore assume a prominent role in the determination of the price level and of inflation (Matthews 1996). This is fully in line with Keynes's (1930 [1971], ch. 10; 1936 [1973]: ch. 19) arguments in the Treatise on Money and in The General Theory, as well as with modern post-Keynesian economics (Hein 2008: part III; Lavoie 2014: ch. 8). It contradicts a determination of the price level, or the rate of inflation, by the quantity of money, or its rate of change, under control of some monetary authorities.

A rejection of the quantity theory of the price level is already contained in Marx's (1867 [1967]: 116-124) discussion of the role of money as a means of circulation. There he argues that the quantity of money necessary for circulation $\left(M_{c}\right)$ is given by the volume of traded commodities $\left(Y^{r}\right)$, the average value or price of these commodities $(p)$, and the velocity of circulation of a unit of money $(q): M_{c}=\left(p Y^{r}\right) / q$. We will come back to endogenous money in Marx's theory further below and only note here that Marx's view is again fully in line with modern post-Keynesian monetary economics, according to which the monetary rate of interest is an exogenous, partly policy-determined variable, and the quantities of credit and money are endogenously determined by pricing and the level of economic activity (Hein 2008: ch. 6; Lavoie 2014: ch. 4) - a view to which Keynes converged back after the publication of The General Theory in his debate with Ohlin, Hawtrey and Robertson in the Economic Journal 1937/1938 (Keynes 1937a [1973]; 1937b [1973]; 1938 [1973]).

Finally, money as a non-reproducible commodity provides the conditions for Marx's rejection of Say's law. The use of money as a means of circulation may interrupt the succession of sales $(C-M)$ and purchases $(M-C)$ in the circuit $C-M-C$. This then leads to Marx's 'possibility theory of crisis', as elaborated in the Theories of Surplus Value (Marx 1861-1863 [1967]: 499-508). The use of money and the possibility of money hoarding, that is, the use of money as a store of value (Marx 1867 [1967]: 130-134) and thus as a non-demand for produced commodities, is the reason why a lack of aggregate demand and a general crisis of overproduction may occur; it is not yet an explanation of why an actual crisis will occur (Crotty 1987; Kenway 1980; Sardoni 1987: 26-36). This underlines again that money has to be non-commodity money in order to sustain Marx's critique of Say's law in his 'possibility theory of crisis' and to pose the problem of effective demand to capitalist economies. This has been made clear by Keynes in the drafts preceding the publication of The General Theory:

Perhaps anything in terms of which the factors of production contract to be remunerated, which is not and cannot be a part of current output and is capable of being used otherwise than to purchase current output, is, in a sense, money. If so, but not otherwise, the use of money is a necessary condition for fluctuations in effective demand. (Keynes 1933a [1979]: 86)

The problem of effective demand and economic stability receives even more attention, if we consider Marx's second argument against Say's law, which derives from the function of money as a means of payment (Marx 1861-1863 [1967]: 511; 1867 [1967]: 134-141). With money as a means of payment, the seller of a commodity becomes a creditor, the buyer a debtor, and money becomes the standard and the subject of a creditor-debtor contract. Money is 'money of account', which according to Keynes (1930 [1971]: 3) 'is the primary concept of a Theory of Money'. In such a credit-money system the demand for commodities is no longer limited by income created in production. The crucial link of expenditure with income and investment with saving in Ricardo's version of Say's law is 
hence relaxed. But money as a means of payment also increases the vulnerability and fragility of the system, because capitalists as debtors do not only need appropriate demand for their produced commodities, but they need it in time in order to be able to meet their payment commitments with their creditors. Unanticipated changes in demand or in market prices for final products may thus cause illiquidity, insolvency and finally default of individual capitals, interrupt credit chains, cause a financial crisis and trigger a general crisis of capital accumulation. We will come back to this in Section 5.

\section{MARX AND KALECKI: SIMPLE AND EXPANDED REPRODUCTION, THE PRINCIPLE OF EFFECTIVE DEMAND, DISTRIBUTION AND GROWTH IN A MONETARY PRODUCTION ECONOMY}

Marx's rejection of Say's law requires a theory of effective demand. Following Kalecki (1968) and Kenway (1980; 1987), the foundations for such a theory can be found in Marx's schemes of simple and expanded reproduction in Capital, Volume 2, chapters XX and XXI (Marx 1885 [1967]: 396-527), which also contain the requirement of endogenous money and credit in a growing capitalist economy. In the schemes of reproduction Marx analyses the conditions for capitalist reproduction in a closed private two-sector model economy. Sector 1 produces means of production and sector 2 produces means of consumption for workers and capitalists. The value of supply of each sector, with unit prices determined by labour values (or by the conditions of production and a distribution parameter as explained in Section 2), is composed of constant capital costs expended in production $(D)$, wage costs $(W)$ and profits (П). In value/price terms, the demand for output of sector 1 consists of gross investment $\left(I^{g}\right)$ in constant capital of both sectors; the demand for output of sector 2 consists of consumption demand out of profits $\left(C_{\Pi}\right)$ and out of wages $\left(C_{w}\right)$. Furthermore, it is assumed that 'workers spend what they get', that is, wages cover a historically given level of subsistence goods consumed by workers and hence $W_{1}=C_{w 1}$ and $W_{2}=C_{w 2}$. From this simple model two important conclusions can be drawn.

First, we obtain from the demand-supply equilibrium in each sector,

$$
D_{1}+W_{1}+\Pi_{1}=I_{1}^{g}+I_{2}^{g}
$$

and

$$
D_{2}+W_{2}+\Pi_{2}=C_{w 1}+C_{\Pi 1}+C_{w 2}+C_{\Pi 2},
$$

the familiar proportionality condition for simple reproduction in a stationary economy, in which there is no net investment:

$$
I_{2}^{g}=C_{w 1}+C_{\Pi 1}
$$

In value/price terms, the supply of investment goods of sector 1 to sector 2 must be equal to the supply of consumption goods of sector 2 to sector 1. Marx (1885 [1967]: ch. XXI) also shows that expanded reproduction and therefore balanced growth in capitalist economies is generally possible, and he derives the proportionality conditions for this as an extension of the condition for simple reproduction.

Second, and more importantly for our purpose, the schemes of reproduction also contribute to the 'possibility theory of crisis' and contain the basics for a theory of effective demand on Marx's grounds. From the equality of aggregate demand and aggregate supply:

$$
D_{1}+W_{1}+\Pi_{1}+D_{2}+W_{2}+\Pi_{2}=I_{1}^{g}+I_{2}^{g}+C_{w 1}+C_{\Pi 1}+C_{w 2}+C_{\Pi 2},
$$


and the assumption that workers do not save, we get:

$$
\Pi_{1}+\Pi_{2}=I_{1}^{n}+I_{2}^{n}+C_{\Pi 1}+C_{\Pi 2}
$$

with $I_{i}^{n}=I_{i}^{g}-D_{i}$ denoting net investment in each sector. From this, Kalecki's (1968) interpretation of Marx's schemes of reproduction arises, which is equivalent to his own theory of profits (Kalecki 1954: ch. 3; Sardoni 1989): Since capitalists cannot determine their sales and profits but can only decide about their expenditures on investment and consumption goods, these expenditures determine profits and thus have to ensure that produced profits will become realised profits. Therefore, investment determines saving in Marx's schemes of reproduction, too. A realisation failure, that is, the inability to sell commodities at expected prices, may occur if there is insufficient investment or consumption demand by capitalists.

In a further step, the determinants of aggregate demand need to be specified, in particular the determinants of investment. However, as is broadly agreed, there is no theory of investment demand in Marx's schemes of reproduction and hence no demand-side determination of the level of output or the rate of growth of the economy (Kalecki 1968; Sebastiani 1991). Of course, there are other parts in Marx's work in which capital accumulation is assumed to be determined by the rate of profit: Capital, Volume 1, ch. XXV, 'The general law of capitalist accumulation', provides a theory of accumulation which has become the foundation for the profit-squeeze theory of economic crisis, and Capital, Volume 3, part III, 'The law of the tendency of the rate of profit to fall', contains a theory of accumulation leading to an overaccumulation crisis based on Marx's specific view on the type of technical change, that is, a tendency of the organic composition of capital $(c / v)$ to rise. ${ }^{10}$ However, both approaches assume that capitalists' expenditures and thus capital accumulation are determined by profits, that is, that saving out of profits determine investment, and hence they do not pay any attention to Marx's views on the role of aggregate demand.

As explained in more detail in Hein (2004a; 2006), Marx's treatment of monetary flows in the schemes of reproduction in Capital, Volume 2, together with other parts in Marx's work on money, interest and credit, provide some important elements for an alternative theory of investment, accumulation and growth on Marx's grounds. Capitalists' expenditures as the causal force of income and profits require that these expenditures can be financed independently of current income and profits. Therefore, capitalists need access to money in order to start the process of production and investment. In his detailed treatment of monetary flows, Marx (1885 [1967]: 329-354, 415-426) shows that even for simple reproduction the circulation of commodities requires advances of money by capitalists.

So far as the entire capitalist class is concerned, the proposition that it must itself throw into circulation the money required for the realization of its surplus-value (correspondingly also for the circulation of its capital, constant and variable) not only fails to appear paradoxical, but stands forth as a necessary condition of the entire mechanism. For there are only two classes: the working class disposing only of its labour-power, and the capitalist class, which has a monopoly of the social means of production and money. (Marx 1885 [1967]: 425)

10. For the short-run version of the profit-squeeze approach explaining business cycles, see Goodwin (1967); for the long-run version explaining economic stagnation, see Glyn/Sutcliffe (1972) and the work in the 'Social-Structure of Accumulation' (SSA) approach, i.e. Gordon (1981; 1995), Gordon et al. (1983; 1987), Kotz (2013) and McDonough et al. (2010). For the 'falling rate of profit due to a rising organic composition of capital' theories, see Catephores (1989: 166-187), Foley (1986b: chs 8-9) and Shaikh (1978a; 1978b; 1987; 2011; 2016: ch. 16). 
As already explained above, the required amount of money to be advanced by capitalists is endogenously determined by the volume of commodities to be traded, the average value/ price of the commodities and the velocity of circulation of a unit of money.

With the values/prices of commodities given, in a growing economy the money advanced by capitalists has to increase. As potential sources for additional money advances and hence for the endogeneity of money, Marx (1885 [1967]: 349-350) proposes the transfer of money from hoards and an increasing velocity of money in circulation (Sardoni 1997). But these sources can only temporarily facilitate an ongoing process of economic expansion, because hoards are finite and the velocity of circulation of money has an upper bound due to payment conventions and institutional factors. In the long run, therefore, the money stock has to increase, according to Marx (1885 [1967]: 350, 494-495) by means of increasing the production of the money commodity. In the context of Marx's 'monetary theory of value', however, we can conceive of the adjustment of the quantity of money to the rate of expansion of the capitalist economy by means of creation and destruction of credit money, following Foley's (1986b: 89) suggestion that '[t]he sustainable rate of growth of the system obviously depends on the level of such new borrowing: the higher the total borrowing, the faster the rate of expanded reproduction that can be achieved by the system'.

As capitalist expansion presupposes the expansion of credit, the conditions of credit are crucial for capital accumulation and economic growth (Sardoni 1989; 1997). The availability and the price of credit, that is, the monetary rate of interest, will therefore have an important impact on effective demand, especially on capitalist investment.

Since the capitalist production process requires monetary advances, the circuit of capital $M-C-M^{\prime}$ will be framed by a credit relation and extends to: $M-M-C-M^{\prime \prime}-M^{\prime}$ (Marx 1894 [1967]: 340), with $M^{\prime}-M=\Pi$ as total profits, $M^{\prime \prime}-M=R$ as interest $(R)$, and $M^{\prime}-M^{\prime \prime}$ as profits of enterprise $\left(\Pi^{n}\right)$. Total profits thus split into profits of enterprise and interest (Marx 1894 [1967]: 358-390):

$$
\Pi=\Pi^{n}+R .
$$

The total rate of profit $(r)$ can now be decomposed analytically into the rate of profit of enterprise $\left(r^{n}\right)$ and the rate of interest, assuming that each sum of money, and thus also own capital advanced by firms, is potentially interest-bearing. Dividing equation (8) by total capital advanced by capitalists gives:

$$
r=r^{n}+i .
$$

Looking at Marx's views on interest and credit in the manuscripts on monetary and financial issues, included by Engels in Capital, Volume 3, it can be argued that they are broadly compatible with the main features of post-Keynesian monetary theory, in particular the 'horizontalist' version put forward by Kaldor (1970; 1982; 1985), Moore (1989) and Lavoie (1984; 1996; 1999), which is also in line with Kalecki's scant writings on monetary issues, according to Sawyer (2001a; 2001b). Following this post-Keynesian view, the rate of interest is a monetary category and a distribution parameter determined by the central bank's monetary policies as well as by the liquidity preference of commercial banks and monetary wealth holders. Credit is generated 'out of nothing' by commercial banks with the volume of credit being determined by that part of credit demand which is considered to be creditworthy. The quantity of central-bank money is endogenously adjusted by the central bank, and determined by the level of economic activity, payment conventions and the willingness of the public to hold cash.

Marx (1894 [1967]: 400-413) does not suppose that credit supply of commercial banks is limited by private saving but assumes that commercial banks can, in principle, 
create credit without limits which will then circulate as credit money (De Brunhoff 1976: 93-99; Reuten 1988):

The credit given by a banker may assume various forms, such as bills of exchange on other banks, cheques on them, credit accounts of the same kind, and finally, if the bank is entitled to issue notes - bank-notes of the bank itself. A bank-note is nothing but a draft upon the banker, payable at any time to the bearer, and given by the banker in place of private drafts. This last form of credit appears particularly important and striking to the layman, first because this form of credit money breaks out of the confines of mere commercial circulation into general circulation, and serves there as money; and because in most countries the principal banks issuing notes, being a particular mixture of national and private banks, actually have the national credit to back them, and their notes are more or less legal tender; because it is apparent here that the banker deals in credit itself, a bank-note being merely a circulating token of credit. (Marx 1894 [1967]: 403-404)

The quantity of credit money is therefore endogenous for capitalist reproduction and is determined by credit demand of capitalists. Analysing the medium of circulation in the credit system, Marx (1894 [1967]: 524) then concludes that ' $t$ ] he quantity of circulation notes is regulated by the turnover requirements, and every superfluous note wends its way back immediately to the issuer'.

According to Marx, the rate of interest is determined in the market for money capital, where there is no 'natural rate' as centre of gravity for actual rates (Marx 1894 [1967]: 358-369). Instead, the rate of interest is given by concrete historical, institutional and political factors which reflect the relative powers of money capital and industrial capital. There is, however, a long-run upper bound for the rate of interest given by the rate of profit, which is assumed to be independent of the former. Only in the sense of setting a long-run maximum limit can the rate of profit be considered to determine the rate of interest (Marx 1894 [1967]: 360). Therefore, the interest rate in Marx's system can be seen as a monetary category determined by the relative powers of industrial and money capital. ${ }^{11}$ With these power relations given, the rate of interest is an exogenous variable for income determination, accumulation and growth, whereas the quantities of credit and money are endogenous.

Also in Marx, the rate of interest is thus a distribution parameter, which mainly affects the distribution of profits between money capitalists and functioning capitalists. Variations in the rate of interest have no influence on the total rate of profits but affect the rate of profit of enterprise inversely:

$[\mathrm{P}]$ rofit of enterprise is not related as an opposite to wage-labour, but only to interest. ...

[A]ssuming the average profit to be given, the rate of the profit of enterprise is not determined by wages, but by the rate of interest. It is high or low in inverse proportion to it. (Marx 1894 [1967]: 379)

From this it follows that Marx's determination of income shares takes place in two stages. In the first stage, Marx considers the rate of profit to be determined by the distribution conflict between capital and labour. With the technical conditions of production given, the rate of profit is determined by the struggle over the real wage rate. In the second stage, the rate of interest is a result of the distribution conflict between money capitalists and industrial capitalists, which makes the rate of profit of enterprise a residual variable.

11. See Argitis (2001), Panico $(1980 ; 1988)$ and Pivetti (1987) for similar results with respect to Marx's theory of the rate of interest, and Sardoni (1997) for some ambiguities in Marx's reasoning. 
Marx's view on the three-party conflict over distribution between labour, industrial capital and financial capital differs from the neo-Ricardian view referred to above, in which the rate of interest and the rate of profit of enterprise are two independent variables, together determining the general rate of profit and making the real wage rate an endogenous variable (Panico 1985; Pivetti 1985; 1987; 1991). As this procedure has to assume a constant rate of profit of enterprise when the interest rate varies, it ignores the distribution conflict between financial capital and industrial capital, which is essential for Marx (Argitis 2001).

Kalecki's (1954: chs 1-2) theory of functional distribution for industrial and service economies is in between Marx's view, on the one hand, and the monetary neo-Ricardian approach, on the other. According to Kalecki, functional income distribution is mainly given by mark-up pricing of firms on constant unit variable costs up to full capacity output. The mark-up, or the degree of monopoly, is determined by the intensity of price competition in the goods market, the relative powers of capital and labour in the labour market, and by overhead costs. According to Kalecki (1954: 18), increasing overhead costs, which include interest paid by firms, may (but need not) cause an increase in the 'degree of monopoly' and hence in the profit share. In Kalecki it thus remains open whether an increase in the rate of interest will reduce the rate of profit of enterprise (at some normal rate of capacity utilisation), as in Marx's view, or the real wage rate, as in the neo-Ricardian view.

Summing up, from these considerations it follows that Marxian accumulation theories based on 'real analysis', that is, the profit-squeeze theory inspired by Capital, Volume 1, chapter XXV, and the overaccumulation theory based on a technologically given fall in the general rate of profit, built on Capital, Volume 3, part III, cannot be sustained if we take Marx's monetary theory and his considerations of the importance of aggregate demand seriously. Capital accumulation cannot be determined by capitalists' saving out of profits, because the realisation of profits requires capitalists' expenditures and thus capital accumulation in the first place. In this version of Marx's theory, profits and thus saving out of profits are dependent on investment, and saving will thus have to adjust to investment. The channels for such an adjustment on Marx's grounds, a change in utilisation of capital stock as in the Kalecki/Steindl version of the post-Keynesian distribution and growth model, or a variation in income distribution as in the Kaldor/Robinson version, are not quite clear. ${ }^{12}$ What is clear, however, is that monetary factors, that is, a monetary rate of interest and credit availability, matter for investment decisions and thus growth. On these grounds, 'general laws of accumulation and crisis' based only on the dynamics of the profit rate are difficult to derive.

\section{MARX AND MINSKY: CREDIT, FINANCIAL FRAGILITY AND CRISES}

As is well known, Minsky $(1975 ; 1977 ; 1986)$ has added financial instability to a basically Kaleckian income-generation process, in which, in the aggregate, capitalists' expenditures determine their profits. Financial fragility depends on the share of credit in investment

12. For the post-Keynesian distribution and growth models, see Hein (2014: chs 4-6). In Capital, Volume 1, Marx (1867 [1967]: 424) mentions a high elasticity of industrial production which would be in line with the Kalecki/Steindl version, which induced Hein (2004a; 2006) to claim that Marx's monetary analysis of distribution and growth could be represented by a monetary extension of the post-Kaleckian distribution and growth model based on the work of Bhaduri/Marglin (1990) and Kurz (1990). Maybe this claim is going a bit too far. 
finance, on the one hand, and on the types of external investment finance, on the other. For the latter, Minsky (1977; 1986 [2008]: 230-232) distinguishes three types of external investment finance: hedge finance, speculative finance and Ponzi finance. With hedge finance, expected future financial revenues are sufficient to serve and repay debt. With speculative finance, expected revenues only cover interest payments but not the repayment of the debt. Maturing debt needs to be rolled over and creditors will have to accept constant levels of debt. Speculative units expect that revenues in later periods will exceed interest payments and/or that prices of assets acquired will rise. Finally, in the case of Ponzi finance, expected revenues are insufficient even for paying interest. For interest to be paid, debt will thus have to increase continuously and will thus explode. Whereas hedge financing units are vulnerable to negative shocks in the goods markets, speculative and Ponzi financing units are furthermore also particularly vulnerable to shocks in the financial markets, since they have to rely on rolling over and/or increasing debt.

Already in Minsky (1975: 127) we find the notion that financial stability generates instability, arguing that 'success breeds daring, and over time the memory of past disaster is eroded. Stability - or even expansion - is destabilizing in that more adventuresome financing of investment pays off to the leaders, and others follow'. The main causes for rising financial fragility in an upswing are rising debt-income or debt-capital ratios and falling shares of hedge finance, but rising importance of speculative and Ponzi finance. When financial fragility rises in an economic upswing and finally in a boom, random shocks, such as an increase in liquidity preference or a policy-induced rise in interest rates, may trigger a financial and economic crisis with debt deflation, defaults and an economic recession, which then has to be terminated by government and/or central-bank interventions.

Marx's notes on credit and instability, incorporated by Engels into Capital, Volume 3, part V, contain some similarities with Minsky's views, as Arnon (1994), Crotty (1986; 1993) and Pollin (1994) have pointed out. But Marx's elaborations also include some important differences, in particular with respect to the interaction of the income-generating process with financial instability. Generally, Marx (1894 [1967]: ch. XXVII) argues that the credit system accelerates economic expansion, on the one hand, but also raises instability, on the other hand:

Hence, the credit system accelerates the material development of the productive forces and the establishment of the world market. It is the historical mission of the capitalist system of production to raise these material foundations of the new mode of production to a certain degree of perfection. At the same time credit accelerates the violent eruptions of this contradiction crises - and thereby the elements of disintegration of the old mode of production. (Marx 1894 [1967]: 441)

According to Marx (1894 [1967]: 360) the accelerating and destabilising effects of the credit system become visible through the counter-movements of the rate of profit and the rate of interest in the course of the business cycle: 'On the whole, then, the movement of loan capital, as expressed in the rate of interest, is in the opposite direction to that of industrial capital' (Marx 1894 [1967]: 489).

The profit-rate dynamics of industrial capital are determined by the movements of capacity utilisation and income distribution in the short run, and by technical change in the long run. A fall in the rate of profit relative to the rate of interest, triggered by a change in any of these factors, will then cause an economic crisis. The interest-rate dynamics are mainly determined by supply of endogenously generated credit, both commercial and bank credit, relative to credit demand, and thus by the willingness to lend relative to the willingness to borrow. From Marx's (1894) remarks in chapters XXVIII 


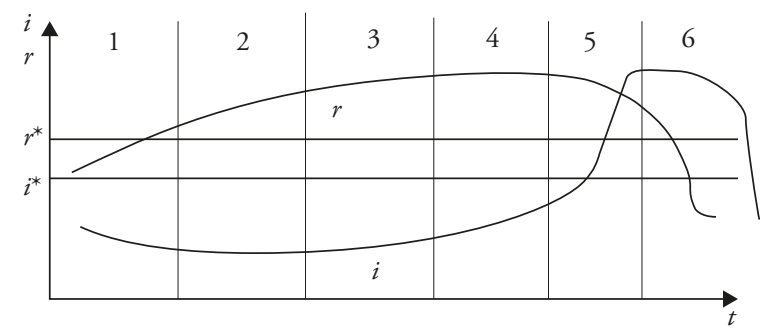

Notes: $r=$ rate of profit; $i=$ rate of interest; $r^{*}=$ average or normal rate of profit; $i^{*}=$ average rate of interest; 1: state of inactivity, 2: mounting revival, 3: prosperity, 4: overproduction, 5: crisis, 6: stagnation. Source: Hein (1997: 269).

Figure 2 Rate of interest and rate of profit in the course of the business cycle according to Marx

and XXX of Capital, Volume 3, the stylised developments of the rate of interest (i) in the credit market and the total rate of profit $(r)$ can be presented as in Figure 2.

The separate phases of the business cycle proposed by Marx (1894 [1967]: 360) show the following characteristics (Marx 1894 [1967]: ch. XXX): in the 'state of inactivity' and in the 'mounting revival', we have a low and only slightly rising rate of profit and an even lower and slightly falling rate of interest. Credit demand is relatively low compared to the willingness to lend. Credit availability at low interest rates thus supports the recovery of capital accumulation after a crisis. The same is true in the phase of 'prosperity' in which the profit rate rises further, associated with an acceleration of capital accumulation, and credit expands because of positive expectations of lenders and borrowers. Rates of interest remain low, but speculative investment starts to rise.

The ready flow and regularity of the returns, linked with extensive commercial credit, ensures the supply of loan capital in spite of the increased demand for it, and prevents the level of the rate of interest from rising. On the other hand, those cavaliers who work without any reserve capital or without any capital at all and who thus operate completely on a money credit basis begin to appear for the first time in considerable numbers. (Marx 1894 [1967]: 488)

In the phase of 'overproduction', capital accumulation and the rate of profit stop rising, however credit continues to expand, mainly due to rising speculation. This causes increasing indebtedness and rising fragility of the system. However, a crisis is triggered by a fall in accumulation and in the rate of profit, which then in the phase of 'crisis' even falls below the rate of interest, which itself rises towards its maximum. The reasons for the latter are debt deflation, defaults, the disruption of credit chains and thus a rising liquidity preference and a falling willingness to lend. The crisis is thus not systematically caused by the degree of indebtedness or the rate of interest, but by a fall in the rate of profit relative to the rate of interest, due to a profit squeeze or a fall in utilisation caused by overinvestment in the previous phases. The collapse of the credit system and the rise of the rate of interest is thus a result of the underlying economic problems, which will then exacerbate the crisis, as Marx (1894 [1967]: 490) points out. Finally, in the phase of 'stagnation' the rate of profit will continue to fall to its minimum, real capital will be devalued, demand for credit will finally fall, and the rate of interest will fall to the level of the profit rate and below, providing the conditions for a new recovery.

Both Marx and Minsky present a story of rising financial fragility in the economic upswing and an acceleration of the downswing by debt deflation and defaults. However, 
the macroeconomics of rising debt-income or debt-capital ratios in an economic upswing are far from obvious, as Lavoie/Seccareccia (2001) have argued with respect to Minsky. Several macroeconomic models have shown that in the economic upswing we may observe a 'paradox of debt' (Steindl 1952 [1976]: 113-121), that is, falling debt-income or debtcapital ratios at the aggregate level in the face of initially rising deficit-financed investment at the firm level (Dutt 1995; Lavoie 1995; Hein 2012). The conditions under which economic expansion is associated with rising debt-income ratios would thus have to be specified from both perspectives.

Apart from this similarity, there is also a major difference between Marx's and Minsky's theories. Minsky sees economic crisis as being caused by financial factors, whereas Marx views economic crisis as being exacerbated by financial fragility but rooted in an underlying contradiction of capitalist reproduction as a whole. Therefore, Marx provides a theory of crisis based on the dynamics of the profit rate relative to the rate of interest, whereas Minsky has to 'rely' on random shocks to an increasingly fragile financial system in order to trigger a crisis. Of course, taking Marx's perspective seriously, there may be several alternative, maybe mutually exclusive reasons why a crisis may arise. Some of them were discussed by Marx in Capital, for example, profit squeeze in Capital, Volume 1, and overaccumulation in Capital, Volume 3, but others were not mentioned by him, for example, accelerating inflation due to escalating distribution conflict in the economic upswing (Hein/ Stockhammer 2010). Yet it is important to notice that Marx has laid the foundations for theories of crisis in which the interactions between economic and financial factors between the rate of profit and the rate of interest and the forces determining their dynamics - are of utmost importance, as was already concluded for the theories of demand and accumulation in the previous section. ${ }^{13}$ In this respect his approach goes beyond Minsky's. ${ }^{14}$

\section{CONCLUSIONS}

In this paper, I have examined the similarities and the differences of Marx's economics with those of Sraffa, Keynes, Kalecki and Minsky. The paper has taken an 'ex post' view on the issue and has mainly looked at the 'output side' of the respective authors, but not at the 'input side', meaning that I have not made any attempt at systematically answering the question of whether and to what extent Sraffa, Keynes, Kalecki and Minsky, or other post-Keynesian authors, were individually influenced by Marx's work. For Keynes and Minsky the answer to such a question would seem to be clear. Keynes hardly studied Marx's work and denied its relevance, and in Minsky's published work there is no reference to Marx, according to Henry (2010). Kalecki, however, was heavily influenced by Marx's contributions, in particular by Capital, Volume 2, which inspired his own theory of demand and profits, but he rejected Marx's labour theory of value and disagreed in several other respects (Sawyer 1985: ch. 8). Sraffa, too, was directly influenced and motivated by Marx's work. The extent to which his contributions should be seen as a fundamental critique or, rather, an amendment of Marx's theory, and to which part of Marx's work which of Sraffa's contributions are mainly related, is still a matter of intense debate (De Vivo/Gilibert 2013; Gehrke/Kurz 2018; Kurz 1979; 2012).

13. See, for example, Crotty (1987) and Ivanova (2012) for different elaborations on Marx's approach towards economic and financial crises.

14. Hein et al. (2015) and Palley (2010) provide a similar assessment with respect to the limitations of Minsky's approach in terms of explaining the financial and economic crisis of 2007-2009. 
Starting from a 'broad tent' understanding of post-Keynesian economics, the review in this paper has shown that Marx's economics share several similarities and compatibilities with the work of Sraffa, Keynes, Kalecki and Minsky, though of course also containing several important differences. With Sraffa, Marx shares the view that long-run relative prices are determined by costs and the requirement of reproduction of the system as a whole. Marx's and Keynes's economics share the characteristics of 'monetary analysis', as defined by Schumpeter (1954: 278), which provides the foundation for the dominance of the 'principle of effective demand' also for long-run analysis. Kalecki has built his theory of aggregate demand and profits on Marx's Capital, Volume 2. Finally, Marx and Minsky share the idea of the potentially destabilising role of financial relations.

Of course, Marx should not be considered as an 'early post-Keynesian', in particular because of several elements of non-monetary and thus 'real analysis' (Schumpeter 1954: 277) in his work, in particular in Capital, Volumes 1 and 3. But he should be regarded as an important forerunner of modern post-Keynesianism, with some similarities and channels of influence, as well as several areas of compatibility. Therefore, it might be advisable for current and future generations of post-Keynesians not to forget about studying Marx alongside, of course, Kalecki, Kaldor, Keynes, Minsky, Robinson, Sraffa, Steindl and so on.

\section{REFERENCES}

Alexander, S. (1940): Mr. Keynes and Mr. Marx, in: Review of Economic Studies, 7, 123-135.

Argitis, G. (2001): Intra-capitalist conflicts, monetary policy and income distribution, in: Review of Political Economy, 13, 453-470.

Arnon, A. (1994): Marx, Minsky and monetary economics, in: Dymski, G., Pollin, R. (eds), New Perspectives in Monetary Economics: Explorations in the Tradition of Hyman P. Minsky, Ann Arbor, MI: University of Michigan Press, 353-365.

Bellofiore, R. (2018): Forever young? Marx's critique of political economy after 200 years, in: PSL Quarterly Review, 71(287), 353-388.

Bhaduri, A., Marglin, S. (1990): Unemployment and the real wage: the economic basis for contesting political ideologies, in: Cambridge Journal of Economics, 14, 375-393.

Boyer, R. (2018): Marx's legacy, regulation theory and contemporary capitalism, in: Review of Political Economy, 30(3), 284-316.

Catephores, G. (1989): An Introduction to Marxist Economics, Basingstoke, UK: Macmillan.

Crotty, J. (1986): Marx, Keynes and Minsky on the instability of the capitalist growth process and the nature of government economic policy, in: Helburn, S.W., Bramhall, D.F. (eds), Marx, Keynes, Schumpeter: A Centennial Celebration of Dissent, New York: M.E. Sharpe, 297-324.

Crotty, J. (1987): The role of money and finance in Marx's crisis theory, in: Union for Radical Political Economics (ed.), The Imperiled Economy: Book I, Macroeconomics from a Left Perspective, New York: Union for Radical Political Economics, 71-82.

Crotty, J. (1993): Rethinking Marxian investment theory: Keynes-Minsky instability, competitive regime shift and coerced investment, in: Review of Radical Political Economies, 25(1), 1-26.

De Brunhoff, S. (1976): Marx on Money, New York: Urizen Books.

De Vivo, G., Gilibert, G. (2013): On Sraffa and Marx: a comment, in: Cambridge Journal of Economics, 37(6), 1443-1447.

Dillard, D. (1984): Keynes and Marx: a centennial appraisal, in: Journal of Post Keynesian Economics, 6, 421-432.

Dutt, A.K. (1984): Stagnation, income distribution and monopoly power, in: Cambridge Journal of Economics, 8, 25-40.

Dutt, A.K. (1995): Internal finance and monopoly power in capitalist economies: a reformulation of Steindl's growth model, in: Metroeconomica, 46, 16-34.

Evans, T. (1997): Marxian theories of credit money and capital, in: International Journal of Political Economy, 27(1), 7-42. 
Fan-Hung (1939): Keynes and Marx on the theory of capital accumulation, money and interest, in: Review of Economic Studies, 7, 28-41.

Fine, B., Saad-Filho, A. (2018): Marx 200: the abiding relevance of the labour theory of value, in: Review of Political Economy, 30(3), 339-354.

Foley, D.K. (1983): On Marx's theory of money, in: Social Concept, 1, 5-19.

Foley, D.K. (1986a): Say's law in Marx and Keynes, in: Cahiers d'Economie Politique, 10/11, 183-194.

Foley, D.K. (1986b): Understanding Capital: Marx's Economic Theory, Cambridge, MA: Harvard University Press.

Foley, D.K. (1987): Money in economic activity, in: Eatwell, J., Milgate, M., Newman, P. (eds), The New Palgrave: A Dictionary of Economics, Vol. 3, London, New York and Tokyo: Macmillan, 519-525.

Foley, D.K. (2000): Recent developments in the labor theory of value, in: Review of Radical Political Economics, 32, 1-39.

Gehrke, C., Kurz, H.D. (2018): Sraffa's constructive and interpretative work, and Marx, in: Review of Political Economy, 30(3), 428-442.

Glick, M., Ehrbar, H. (1987): The transformation problem: an obituary, in: Australian Economic Papers, 26, 294-317.

Glyn, A., Sutcliffe, B. (1972): Capitalism in Crisis, New York: Pantheon.

Goodwin, R. (1967): A growth cycle, in: Feinstein, C.H. (ed.), Capitalism and Economic Growth, Cambridge, UK: Cambridge University Press, 54-58.

Gordon, D.M. (1981): Capital-labor conflict and the productivity slowdown, in: American Economic Review, Papers and Proceedings, 71, 30-35.

Gordon, D.M. (1995): Growth, distribution, and the rules of the game: social structuralist macro foundations for a democratic economic policy, in: Epstein, G.A., Gintis, H.M. (eds), Macroeconomic Policy After the Conservative Era, Cambridge, UK: Cambridge University Press, 335-383.

Gordon, D., Weisskopf, T.E., Bowles, S. (1983): Long swings and the nonreproductive cycle, in: American Economic Review, Papers and Proceedings, 73, 152-157.

Gordon, D.M., Weisskopf, T.E., Bowles, S. (1987): Power, accumulation and crisis: the rise and the demise of the postwar social structure of accumulation, in: Union for Radical Political Economics (ed.), The Imperiled Economy, Book I: Macroeconomics from a Left Perspective, New York: Union for Radical Political Economics, 43-57.

Harcourt, G.C. (1969): Some Cambridge controversies in the theory of capital, in: Journal of Economic Literature, 7, 369-405.

Harcourt, G.C. (1972): Some Cambridge Controversies in the Theory of Capital, Cambridge, UK: Cambridge University Press.

Hein, E. (1997): Geld, effektive Nachfrage und Kapitalakkumulation: Eine Betrachtung aus Marxscher, Keynesscher und post-keynesianischer Perspektive, Berlin: Duncker \& Humblot.

Hein, E. (2004a): Money, credit and the interest rate in Marx's economics: on the similarities of Marx's monetary analysis to post-Keynesian economics, in: International Papers in Political Economy, 11(2), 1-43.

Hein, E. (2004b): Verteilung und Wachstum: eine paradigmenorientierte Einführung unter besonderer Berücksichtigung der post-keynesianischen Theorie, Marburg: Metropolis.

Hein, E. (2006): Money, interest and capital accumulation in Karl Marx's economics: a monetary interpretation and some similarities to post-Keynesian approaches, in: European Journal of the History of Economic Thought, 13(1), 113-140.

Hein, E. (2008): Money, Distribution Conflict and Capital Accumulation: Contributions to 'Monetary Analysis', Basingstoke, UK: Palgrave Macmillan.

Hein, E. (2012): The rate of interest as a macroeconomic distribution parameter: horizontalism and post-Keynesian models of distribution and growth, in: Bulletin of Political Economy, 6, $107-132$.

Hein, E. (2014): Distribution and Growth After Keynes: A Post-Keynesian Guide, Cheltenham, UK and Northampton, MA: Edward Elgar Publishing.

Hein, E. (2017): Post-Keynesian macroeconomics since the mid-1990s: main developments, in: European Journal of Economics and Economic Policies: Intervention, 14(2), 131-172. 
Hein, E. (2018a): The principle of effective demand: Marx, Kalecki, Keynes and beyond, in: Jo, T.-H., Chester, L., D'Ippoliti, C. (eds), The Routledge Handbook of Heterodox Economics: Theorizing, Analyzing, and Transforming Capitalism, Abingdon, UK and New York: Routledge, 84-100.

Hein, E. (2018b): Inequality and growth: Marxian and post-Keynesian/Kaleckian perspectives on distribution and growth regimes before and after the Great Recession, in: Arestis, P. Sawyer, M. (eds), Inequality: Trends, Causes, Consequences, Relevant Policies - International Papers in Political Economy, Basingstoke, UK: Palgrave Macmillan, 89-137.

Hein, E. (2018c): Verteilung und Wachstum: eine paradigmenorientierte Einführung unter besonderer Berücksichtigung der post-keynesianischen Theorie, zweite, grundlegend überarbeitete und stark erweiterte Auflage, Marburg: Metropolis.

Hein, E., Stockhammer, E. (2010): Macroeconomic policy mix, employment and inflation in a post-Keynesian alternative to the New Consensus Model, in: Review of Political Economy, 22, 317-354.

Hein, E., Dodig, N., Budyldina, N. (2015): The transition towards finance-dominated capitalism: French Regulation School, Social Structures of Accumulation and post-Keynesian approaches compared, in: Hein, E., Detzer, D., Dodig, N. (eds), The Demise of Finance-dominated Capitalism: Explaining the Financial and Economic Crises, Cheltenham, UK and Northampton, MA: Edward Elgar Publishing, 7-53.

Heinrich, M. (1991): Die Wissenschaft vom Wert, Hamburg: VSA.

Helmedag, F. (2012): Principles of capitalist commodity production, in: European Journal of Economics and Economic Policies: Intervention, 9(1), 23-34.

Helmedag, F. (2018): Warenproduktion mittels Arbeit: zur Rehabilitation des Wertgesetzes, 3rd, revised and expanded edn, Marburg: Metropolis.

Henry, J.F. (2010): Minsky, Marx, Veblen and Chicago, Levy Institute Minsky Summer School, 19-26 June, URL: http://www.levyinstitute.org/pubs/Henry.pdf.

Howard, M.C., King, J.E. (2018): Marx@200, in: Review of Political Economy, 30(3), 317-338.

Hunt, E.K., Glick, M. (1987): Transformation problem, in: Eatwell, J., Milgate, M., Newman, P. (eds), The New Palgrave: A Dictionary of Economics, Vol. 4, London, New York and Tokyo: Macmillan, 688-690.

Ivanova, M.N. (2012): Marx, Minsky and the Great Recession, in: Review of Radical Political Economics, 45(1), 59-75.

Kaldor, N. (1955/1956): Alternative theories of distribution, in: Review of Economic Studies, 23, 83-100.

Kaldor, N. (1970): The new monetarism, in: Lloyds Bank Review, 97, 1-17.

Kaldor, N. (1982): The Scourge of Monetarism, Oxford: Oxford University Press.

Kaldor, N. (1985): How monetarism failed, in: Challenge, May/June, 4-13.

Kalecki, M. (1954): Theory of Economic Dynamics, London: George Allen and Unwin.

Kalecki, M. (1968): The Marxian equations of reproduction and modern economics, in: Social Science Information, 7, 73-79.

Kenway, P. (1980): Marx, Keynes and the possibility theory of crisis, in: Cambridge Journal of Economics, 4, 23-36.

Kenway, P. (1987): Realization problem, in: Eatwell, J., Milgate, M., Newman, P. (eds), The New Palgrave: A Dictionary of Economics, Vol. 4, London, New York and Tokyo: Macmillan, 105-107.

Keynes, J.M. (1930 [1971]): A Treatise on Money, Volume I, The Collected Writings of J.M. Keynes, Vol. V, London and Basingstoke, UK: Macmillan.

Keynes, J.M. (1933a [1979]): Towards the General Theory, in: The Collected Writings of John Maynard Keynes, Vol. XXIX, The General Theory and After: A Supplement, London: Macmillan, $35-160$.

Keynes, J.M. (1933b [1973]): A monetary theory or production, in: The Collected Writings of John Maynard Keynes, Vol. XIII, The General Theory and After, Part I, Preparation, London: Macmillan, 408-411.

Keynes, J.M. (1934 [2013]): Letter to Bernard Shaw, 2 December 1934, in: The Collected Writings of John Maynard Keynes, Vol. XXVIII, Social, Political and Literary Writings, Cambridge, UK: Cambridge University Press, 38.

Keynes, J.M. (1936 [1973]): The General Theory of Employment, Interest and Money, The Collected Writings of J.M. Keynes, Vol. VII, London: Macmillan. 
Keynes, J.M. (1937a [1973]): Alternative theories of the rate of interest, in: The Collected Writings of John Maynard Keynes, Vol. XIV, The General Theory and After, Part II, Defence and Development, London: Macmillan, 201-215.

Keynes, J.M. (1937b [1973]): 'Ex ante' theory of the rate of interest, in: The Collected Writings of John Maynard Keynes, Vol. XIV, The General Theory and After, Part II, Defence and Development, London: Macmillan, 215-223.

Keynes, J.M. (1938 [1973]): Mr. Keynes on 'finance', in: The Collected Writings of John Maynard Keynes, Vol. XIV, The General Theory and After, Part II, Defence and Development, London: Macmillan, 229-233.

Kotz, D.M. (2013): Social structures of accumulation, the rate of profit, and economic crises, in: Wicks-Lim, J., Pollin, R. (eds), Capitalism on Trial: Explorations in the Tradition of Thomas E. Weisskopf, Cheltenham, UK and Northampton, MA: Edward Elgar Publishing, 335-349.

Kurz, H.D. (1979): Sraffa after Marx, in: Australian Economic Papers, 18(32), 52-70.

Kurz, H.D. (1990): Technical change, growth and distribution: a steady-state approach to 'unsteady' growth', in: Kurz, H.D., Capital, Distribution and Effective Demand, Cambridge, UK: Polity Press, 210-239.

Kurz, H.D. (2012): Don't treat to ill my Piero! Interpreting Sraffa's papers, in: Cambridge Journal of Economics, 36, 1535-1569.

Kurz, H.D. (2018a): Hin zu Marx und über ihn hinaus, in: Perspektiven der Wirtschaftspolitik, 19(3), 245-266.

Kurz, H.D. (2018b): Marx and the 'law of value': a critical appraisal on the occasion of his 200th birthday, in: Investigacion Economica, 77(304), 40-71.

Lavoie, M. (1984): The endogenous flow of credit and the post Keynesian theory of money, in: Journal of Economic Issues, 18, 771-797.

Lavoie, M. (1995): Interest rates in post-Keynesian models of growth and distribution, in: Metroeconomica, 46, 146-177.

Lavoie, M. (1996): Horizontalism, structuralism, liquidity preference and the principle of increasing risk, in: Scottish Journal of Political Economy, 43, 275-300.

Lavoie, M. (1999): The credit-led supply of deposits and the demand for money: Kaldor's reflux mechanism as previously endorsed by Joan Robinson, in: Cambridge Journal of Economics, 23, $103-113$.

Lavoie, M. (2006): Introduction to Post-Keynesian Economics, Basingstoke, UK: Palgrave Macmillan.

Lavoie, M. (2014): Post-Keynesian Economics: New Foundations, Cheltenham, UK and Northampton, MA: Edward Elgar Publishing.

Lavoie, M., Seccareccia, M. (2001): Minsky's financial fragility hypothesis: a missing macroeconomic link?, in: Bellofiore, R., Ferri, P. (eds), Financial Fragility and Investment in the Capitalist Economy: The Economic Legacy of Hyman Minsky, Cheltenham, UK and Northampton, MA: Edward Elgar Publishing, 76-96.

Lazzarini, A. (2011): Revisiting the Cambridge Capital Controversies: A Historical and Analytical Study, Pavia: Pavia University Press.

Marx, K. (1861-1863 [1967]): Theorien über den Mehrwert, Zweiter Teil, Marx-Engels-Werke, Bd. 26.2, Berlin: Dietz Verlag.

Marx, K. (1867 [1967]): Capital: A Critique of Political Economy, Volume 1, The Process of Capitalist Production, translated from the 3rd German edn, New York: International Publishers.

Marx, K. (1885 [1967]): Capital: A Critique of Political Economy, Volume 2, The Process of Circulation of Capital, translated from the 2nd German edn, New York: International Publishers.

Marx, K. (1894 [1967]): Capital: A Critique of Political Economy, Volume 3, The Process of Capitalist Production as a Whole, New York: International Publishers.

Matthews, P.H. (1996): The modern foundations of Marx's monetary economics, in: The European Journal of the History of Economic Thought, 3, 61-83.

McDonough, T., McMahon, C. (2018): Marxism, crypto-Marxism and the political economy of capitalism, in: Review of Political Economy, 30(3), 396-415.

McDonough, T., Reich, M., Kotz, D.M. (eds) (2010): Contemporary Capitalism and its Crises: Social Structure of Accumulation Theory for the 21st Century, Cambridge, UK: Cambridge University Press. 
Minsky, H. (1975): John Maynard Keynes, London: Macmillan.

Minsky, H. (1977): The financial instability hypothesis, in: Challenge, March/April, 20-27.

Minsky, H.P. (1986 [2008]): Stabilizing an Unstable Economy, reprint, New York: McGraw-Hill. Moore, B. (1989): The endogeneity of credit money, in: Review of Political Economy, 1, 65-93.

Moss, S. (1980): The end of orthodox capital theory, in: Nell, E. (ed.), Growth, Profits, and Property: Essays in the Revival of Political Economy, Cambridge, UK: Cambridge University Press, 64-79.

Palley, T. (2010): The limits of Minsky's financial instability hypothesis as an explanation of the crisis, in: Monthly Review, 61(11), 28-43.

Panico, C. (1980): Marx's analysis of the relationship between the rate of interest and the rate of profit, in: Cambridge Journal of Economics, 4, 363-378.

Panico, C. (1985): Market forces and the relation between the rate of interest and profit, in: Contributions to Political Economy, 4, 37-60.

Panico, C. (1988): Marx on the banking sector and the interest rate: some notes for a discussion, in: Science and Society, 52, 310-325.

Pivetti, M. (1985): On the monetary explanation of distribution, in: Political Economy, 1, 73-103.

Pivetti, M. (1987): Interest and profit in Smith, Ricardo and Marx, in: Political Economy, 3, 63-74.

Pivetti, M. (1991): An Essay on Money and Distribution, Basingstoke and London, UK: Macmillan.

Pollin, R. (1994): Marxian and post-Keynesian developments in the sphere of money, credit and finance: building alternative perspectives in monetary macroeconomics, in: Glick, M. (ed.), Competition, Technology and Money, Aldershot, UK and Brookfield, VT: Edward Elgar Publishing, 97-117.

Reuten, G. (1988): The money expression of value and the credit system: a value-form theoretic outline, in: Capital \& Class, 35, 121-141.

Reuten, G. (1995): Conceptual collapses: a note on value-form theory, in: Review of Radical Political Economics, 27, 104-110.

Robinson, J. (1942): An Essay on Marxian Economics, London: Macmillan.

Robinson, J. (1962): Essays in the Theory of Economic Growth, London: Macmillan.

Robinson, J. (1966): Marx and Keynes, in: Robinson, J., Collected Economic Papers, Volume One, Oxford: Basil Blackwell, 133-145.

Rotheim, R.J. (1991): Marx, Keynes and the theory of a monetary economy, in: Caravale, G.A. (ed.), Marx and Modern Economic Analysis, Vol. II, Aldershot, UK and Brookfield, VT: Edward Elgar Publishing, 240-263.

Rowthorn, R.E. (1981): Demand, real wages and economic growth, in: Thames Papers in Political Economy, Autumn, 1-39.

Rubin, I.I. (1928 [1973]): Studien zur Marxschen Werttheorie, German translation of an unpublished US translation based on the 3rd edn of the Russian original, Frankfurt am Main: Europäische Verlagsanstalt.

Sardoni, C. (1987): Marx and Keynes on Economic Recession, Brighton, UK: Wheatsheaf Books.

Sardoni, C. (1989): Some aspects of Kalecki's theory of profits: its relationship to Marx's schemes of reproduction, in: Sebastiani, M. (ed.), Kalecki's Relevance Today, New York: St. Martin's Press, 206-219.

Sardoni, C. (1997): Keynes and Marx, in: Harcourt, G.C., Riach, P. (eds), A 'Second Edition' of the General Theory, Vol. II, London: Routledge.

Sardoni, C. (2011): Unemployment, Recession and Effective Demand: The Contributions of Marx, Keynes and Kalecki, Cheltenham, UK and Northampton, MA: Edward Elgar Publishing.

Sawyer, M. (1985): The Economics of Michal Kalecki, Armonk, NY: M.E. Sharpe.

Sawyer, M. (2001a): Kalecki on money and finance, in: European Journal of the History of Economic Thought, 8, 487-508.

Sawyer, M. (2001b): Kalecki on imperfect competition, inflation and money, in: Cambridge Journal of Economics, 25, 245-261.

Schumpeter, J.A. (1954): History of Economic Analysis, New York: Oxford University Press.

Sebastiani, M. (1991): Observations on Marx's and Kalecki's approaches to the theory of effective demand, in: Caravale, G.A. (ed.), Marx and Modern Economic Analysis, Vol. II, Aldershot, UK and Brookfield, VT: Edward Elgar Publishing, 264-282. 
Shaikh, A. (1978a): An introduction to the history of crisis theories, in: Union for Radical Political Economics (ed.), US Capitalism in Crisis, New York: Union for Radical Political Economics, 219-241.

Shaikh, A. (1978b): Political economy and capitalism: notes on Dobb's theory of crisis, in: Cambridge Journal of Economics, 2, 233-251.

Shaikh, A. (1987): The falling rate of profit and the economic crisis in the U.S., in: Union for Radical Political Economics (ed.), The Imperiled Economy, Book I, Macroeconomics from a Left Perspective, New York: Union for Radical Political Economics, 115-126.

Shaikh, A. (2011): The first great depression of the 21st century, in: Socialist Register, 47, 44-63.

Shaikh, A. (2016): Capitalism: Competition, Conflict, Crises, Oxford: Oxford University Press.

Smithin, J. (1994): Controversies in Monetary Economics: Ideas, Issues and Policy, Aldershot, UK and Brookfield, VT: Edward Elgar Publishing.

Sraffa, P. (1960): Production of Commodities by Means of Commodities, Cambridge, UK: Cambridge University Press.

Steedman, I. (1977): Marx After Sraffa, London: NLB.

Steindl, J. (1952 [1976]): Maturity and Stagnation in American Capitalism, 2nd edn, New York: Monthly Review Press.

Toporowski, J. (2018): Marx, finance and political economy, in: Review of Political Economy, 30(3), 416-427.

Von Bortkiewicz, L. (1907): Zur Berichtigung der grundlegenden theoretischen Diskussion von Marx im dritten Band des Kapitals, in: Jahrbücher für Nationalökonomie und Statistik, 34, 319-335.

Williams, M. (2000): Why Marx neither has nor needs a commodity theory of money, in: Review of Political Economy, 12, 435-451. 